\title{
Analisis Minat Pelajar terhadap Aplikasi-Aplikasi Penunjang Sistem Pembelajaran Online
}

\author{
Azza Arba Nurul Ummah \\ Pendidikan Fisika, FKIP, Universitas Sebelas Maret \\ Email: azzaarba222@gmail.com
}

\begin{abstract}
ABSTRAK
Pandemi COVID-19 telah menjadi hambatan dalam melaksanakan aktivitas kehidupan. Dengan adanya pandemi ini, dunia pendidikan melakukan sistem pembelajaran baru yaitu dengan sistem pembelajaran online atau e-learning. Dalam sistem pembelajaran ini juga menggunakan aplikasi penunjang pembelajaran yang memiliki tingkat keefektifan yang berbeda-beda. Penelitian ini bertujuan untuk mengetahui tingkat minat aplikasi penunjang pembelajaran online tersebut berdasarkan survei aplikasi yang menurut responden paling efektif untuk digunakan dalam pembelajaran online. Penelitian ini menggunakan metode survei kualitatif dan teknik pengumpulan datanya adalah menggunakan teknik angket atau kuesioner. Selain itu, kuesioner yang digunakan adalah jenis kuesioner semi terbuka serta pengambilan hasil datanya dilakukan dengan teknik presentase. Hasil penelitian menunjukkan bahwa aplikasi Zoom memiliki perolehan presentase yang paling besar diikuti dengan aplikai Google Meet yang mengindikasikan bahwa aplikasi Zoom dan Google Meet merupakan aplikasi yang paling diminati untuk digunakan dalam pembelajaran online.
\end{abstract}

Kata kunci : Online, aplikasi pembelajaran, minat

\section{ABSTRACT}

The COVID-19 pandemic has become an obstacle in carrying out life activities. With this pandemic, the world of education is implementing a new learning system, namely the online learning system or e-learning. In this learning system also uses learning support applications that have different levels of effectiveness. This study aims to determine the level of interest in online learning support applications based on a survey of applications which according to respondents are the most effective for use in online learning. This study uses a qualitative survey method and the data collection technique is using a questionnaire technique. In addition, the questionnaire used was a semi-open questionnaire and the data collection was done using a percentage technique. The results show that the Zoom application has the largest percentage gain followed by the Google Meet application which indicates that the Zoom application and Google Meet application are the most popular applications to be used in online learning.

Keywords: Online, learning application, interest 


\section{PENDAHULUAN}

Munculnya wabah penyakit baru di akhir tahun 2019 telah mengejutkan masyarakat di seluruh dunia. Wabah yang diketahui muncul pertama kali di daerah Wuhan, China ini menjadi masalah yang sangat serius dan sampai sekarang masih menjadi problematika paling besar yang dialami oleh banyak negara di seluruh dunia. Wabah penyakit baru tersebut dinamakan COVID-19 ( coronavirus 2019 ) yaitu sebuah penyakit menular yang disebabkan oleh sindrom pernapasan akut corona virus 2 (SARS-CoV-2). Pada awalnya, wabah virus ini hanya melanda di Wuhan, China, dan daerah sekitarnya. Namun, seiring berjalannya waktu, wabah virus ini semakin menyebar ke berbagai negara salah satunya di Indonesia. Wabah virus ini mulai masuk ke Indoenesia di awal tahun 2020 dan dari waktu ke waktu perkembangan virus ini semakin meningkat hingga sekarang. Penyebaran virus ini yang meluas ke seluruh dunia menjadikan kasus virus corona masuk dalam kategori pandemi.

Pandemi COVID-19 telah menjadi hambatan bagi banyak orang dalam melaksanakan aktivitas kehidupan. Pasalnya, virus tersebut adalah virus menular sehingga perlu berhati-hati jika kita hendak ke luar rumah atau bertemu dengan banyak orang di luar. Akibatnya, aktivitas kehidupan normal perlu dibatasi dengan suatu sistem aturan kehidupan yang baru untuk tindakan preventif penularan virus korona itu sendiri. Di wilayah dengan tingkat penyebaran virus corona yang tinggi, sudah ada yang menerapkan sistem lockdown atau menutup total semua aktivitas kehidupan di luar rumah. Sehingga setiap orang hanya diperbolehkan melakukan segala sesuatu berada di dalam rumah. Di Indonesia, pemerintah tidak memberlakukan sistem lockoawn tetapi telah mengeluarkan kebijakan sistem new normal. Artinya, masyarakat bisa melakuakn aktivitas normal seperti biasanya namun harus tetap mematuhi protokol kesehatan yang telah ditetapkan.

Dalam dunia pendidikan, sistem new normal dilakukan dalam bentuk pembelajaran online atau pembelajaran e-learning. Dalam sistem ini, para pelajar tidak dikenakan datang secara langsung ke tempat pendidikan seperti biasanya karena akan sangat riskan. Namun, beberapa wilayah di Indonesia yang tingkat penyebaran virus coronanya rendah, masih melakukan kegiatan pembelajaran tatap muka secara langsung, tetapi dengan aturan yang sedikit berbeda dan harus tetap mematuhi protokol kesehatan.

Adanya sistem pembalajaran online, baik pengajar maupun pelajar harus dituntut untuk terbiasa dengan sistem pembelajaran baru dan harus dipersiapakan segala hal yang diperlukan dalam pembelajaran online itu sendiri, misalnya media belajar seperti laptop, smartphone, kuota internet, aplikasi belajar, dan lain sebagainya. Dalam pembelajaran online atau e-learning biasanya harus menggunakan aplikasi penunjang pembelajaran. Ada banyak sekali aplikasi-aplikasi pembelajaran yang bisa digunakan dalam pendidikan tergantung kehendak dari masing-masing subjek. Dalam penelitian ini bertujuan untuk mengetahui tingkat peminatan aplikasi penunjang pembelajaran online yang nantinya akan diperoleh hasil yaitu terkait dengan aplikasi manakah yang paling diminati oleh responden berdasarkan aplikasi yang menurut responden paling efektif untuk digunakan dalam pembelajaran online. 


\section{METODE PENELITIAN}

Penelitian ini dilakukan menggunakan metode survei kualitatif. Singarimbun ( dalam Hendrawati.1982:3) dalam metode penelitian survei mengatakan bahwa penelitian survei adalah "penelitian yang mengambil sampel dari satu populasi dan menggunakan kuesioner sebagai alat pengumpulan data yang pokok." Sedangkan menurut Tika (dalam Hendrawati.1997:9) mengatakan bahwa "survey adalah suatu metode penelitian yang bertujuan untuk mengumpulkan sejumlah besar data berupa variabel, unit atau individu dalam waktu yang bersamaan, data dikumpulkan melalui individu atau sampel fisik tertentu dengan tujuan agar dapat menggeneralisasikan terhadap apa yang diteliti. Variabel yang dikumpulkan dapat bersifat fisik maupun sosial". Penelitian dengan metode kualitatif sebenarnya akan menghasilkan penemuan-penemuan yang tidak diperoleh dengan cara statistik atau pengukurang-pngukuran tertentu. Akan tetapi, dalam penelitian ini terdapat metode atau teknik yang melibatkan suatu jenis pengukuran. Namun, tujuan sebenarnya dari penelitian ini lebih berfokus pada penyimpulan kualitatif karena di sini akan menganalisis tingkat peminatan sejumlah orang terhadap sesuatu. Teknik pengukuran di sini dilakukan sebagai alat bantu penelitian.

Dalam penelitian ini, metode survei kualitatif digunakan untuk mendapatkan informasi mengenai efektivitas dari aplikasi belajar berdasarkan pandangan pelajar atau pengguna aplikasi pembelajaran online. Teknik pengumpulan data yang digunakan adalah teknik angket atau kuisioner. Menurut Sugiyono (dalam Hendrawati.2011:) angket atau kuesioner merupakan teknik pengumpulan data yang dilakukan dengan cara memberi seperangkat pertanyaan atau pernyataan tertulis kepada responden untuk dijawab.

Menurut Arikunto (dalam Hendrawati.2010:268) prosedur penyusunan angket adalah sebagai berikut:

1) Merumuskan tujuan yang akan dicapai dalam kuesioner.

2) Mengidentifikasi variabel yang akan dijadikan sasaran kuesioner.

3) Menjabarkan setiap variabel menjadi sub-variabel yang lebih spesifik dan tunggal.

4) Menentukan jenis data yang akan dikumpulkan, sekaligus untuk menentukan teknik analisisnya.

Berdasarkan bentuk pertanyaannya, kuesioner dibagi dalam dua jenis, yakni kuesioner terbuka dan kuesioner tertutup. Kuesioner terbuka adalah kuesioner yang memberikan kebebasan kepada objek penelitian untuk menjawab. Sementara itu, kuesioner tertutup adalah kuesioner yang telah menyediakan pilihan jawaban untuk dipilih oleh objek penelitian. Seiring dengan perkembangan, beberapa penelitian saat ini juga menerapkan metode kuesioner yang memiliki bentuk semi terbuka. Dalam bentuk ini, pilihan jawaban telah diberikan oleh peneliti, namun objek penelitian tetap diberi kesempatan untuk menjawab sesuai dengan kemauan mereka. 
Penelitian ini menggunakan bentuk pertanyaan kuesioner semi terbuka di mana responden telah disediakan pertanyaan oleh peneliti dan jawaban dari pertanyaan sebagian telah disediakan oleh peneliti dalam bentuk pilihan serta sebagiannya lagi dibebaskan kepada responden untuk menjawab sesuai dengan pendapat masing-masing responden. Responden diberikan beberapa pertanyaan sederhana yang nantinya akan diambil hasil penelitian dan kesimpulan mengenai efektivitas aplikasi pembelajaran online menurut responden itu sendiri. Pertanyaan yang diajukan adalah :

1. Siapa nama responden?

2. Apa status pendidikan dari responden?

Status pendidikan dijawab berupa status sebagai siswa/siswi tingkat SMA dan mahasiswa/mahasiswi.

3. Apa tingkat kelas dari responden?

Tingkat kelas dijawab berupa tingkatan kelas dari responden, apabila siswa SMA maka diisi dengan kelas 1/2/3, sedangkan apabila responden seorang mahasiswa maka diisi tingkat semester yang ditempuh saat ini.

4. Aplikasi manakah yang menurut responden paling efektif dalam pembelajaran daring? Responden dikenakan memilih di anatara pilihan yang telah disediakan dalam kuesioner yaitu ada Zoom, Google Meet, WhatsApp Group, Google Classroom, dan lainnya.

5. Apa alasan responden memilih aplikasi tersebut?

Teknik analisis data dalam penelitian ini menggunakan teknik analisis persentase. Analisis persentase adalah suatu cara yang digunakan untuk melihat seberapa banyak kecenderungan frekuensi jawaban responden dan fenomena-fenomena di lapangan. Langkah ini juga dilakukan untuk melihat besar kecilnya proporsi dari setiap jawaban pada setiap pertanyaan sehingga data yang diperolah selanjutnya mudah untuk dianalisa (Hendrawati:2016).

Teknik persentase dalam penelitian ini dilakukan dengan melalui prosedur di bawah ini :

a) Pemeriksaan data

Memeriksa data yang diperoleh dari jawaban responden pada kuesioner mengenai kelengkapan jawabannya.

b) Klasifikasi data

Mengklasifikasi atau menggolongkan data sesuai dengan kriteria dan tujuan yang telah ditentukan untuk memudahkan dalam perhitungan.

c) Menghitung frekuensi jawaban dari masing-masing kriteria yang telah ditentukan.

d) Menghitung persentase dengan teknik persentase dari setiap data yang diperoleh.

Dalam perhitungan persentase dari setiap data, digunakan rumus seperti berikut ini : 


$$
P=\frac{F}{n} \times 100 \%
$$

$$
\begin{array}{ll}
\text { Keterangan : } & \mathrm{P}=\text { besaran presentase } \\
& \mathrm{F}=\text { frekuensi jawaban } \\
& \mathrm{n}=\text { jumlah total responden }
\end{array}
$$

\section{HASIL PENELITIAN DAN PEMBAHASAN}

Hasil penelitian dipeoleh berdasarkan jawaban dari responden yang telah diajukan dalam kuesioner. Adapun hasil penelitian dalam kuesioner dipilih dari beberapa pertanyaan yang paling utama yang berpengaruh dan berhubungan dengan topik efekivitas aplikasi pembelajaran online. Hasil penelitian berupa jawaban dari responden antara lain :

1. Aplikasi manakah yang menurut responden paling efektif dalam pembelajaran daring?

Jawaban responden :

Jawaban dari responden dirincikan dalam bentuk tabel dan juga diagram batang agar lebih terstruktur dan mudah dipahami.

\begin{tabular}{|c|c|c|c|c|c|}
\hline \multirow{2}{*}{ Responden } & \multicolumn{5}{|c|}{ Aplikasi Pilihan Responden } \\
\cline { 2 - 6 } & Zoom & $\begin{array}{c}\text { Google } \\
\text { Meet }\end{array}$ & $\begin{array}{c}\text { Google } \\
\text { Classroom }\end{array}$ & $\begin{array}{c}\text { WhatsApp } \\
\text { Group }\end{array}$ & Lainnya \\
\hline $\begin{array}{c}\text { Siswa/siswi SMA } \\
\text { Kelas 1-3 }\end{array}$ & 15 & 10 & & 2 & 3 \\
\hline $\begin{array}{c}\text { Mahasiswa/Mahasiswi } \\
\text { SEM 1 }\end{array}$ & 15 & 8 & 2 & 1 & 1 \\
\hline $\begin{array}{c}\text { Mahasiswa/Mahasiswi } \\
\text { SEM 2 }\end{array}$ & 1 & 1 & 1 & 1 & 4 \\
\hline $\begin{array}{c}\text { Mahasiswa/Mahasiswi } \\
\text { SEM 3 }\end{array}$ & 4 & 19 & 3 & 8 & \\
\hline $\begin{array}{c}\text { Mahasiswa/Mahasiswi } \\
\text { SEM >3 }\end{array}$ & 20 & & & \\
\hline Total & & & & & \\
\hline
\end{tabular}

Hasil penelitian juga akan dilakukan teknik presentase data yang diperoleh dari total keseluruhan masing-masing pengguna aplikasi pembelajaran. Teknik presentase data menggunakan rumus sebagai berikut :

$$
P=\frac{F}{n} \times 100 \%
$$

Keterangan : $\quad \mathrm{P}=$ besaran presentase

$\mathrm{F}=$ frekuensi jawaban 


$$
\mathrm{n}=\text { jumlah total responden }
$$

Hasil penelitian mengungkapkan bahwa sebanyak 54 orang telah menjawab pertanyaan dalam kuesioner sehingga jumlah total responden (n) adalah sebanyak 54 responden. Sedangkan untuk frekuensi jawaban terhadap aplikasi yang dipilih oleh masing-masing responden dijabarkan dalam tabel berikut.

\begin{tabular}{|c|c|}
\hline Aplikasi & Frekuensi (F) \\
\hline Zoom & 20 \\
\hline Google Meet & 19 \\
\hline Google Classroom & 3 \\
\hline WhatsApp Grup & 8 \\
\hline Lainnya & 4 \\
\hline
\end{tabular}

1) Presentase responden yang memilih aplikasi Zoom

$$
\begin{gathered}
P=\frac{F}{n} \times 100 \% \\
P=\frac{20}{54} \times 100 \%=37 \%
\end{gathered}
$$

2) Presentase responden yang memilih aplikasi Google Meet

$$
\begin{gathered}
P=\frac{F}{n} \times 100 \% \\
P=\frac{19}{54} \times 100 \%=35 \%
\end{gathered}
$$

3) Presentase responden yang memilih aplikasi Google Classroom

$$
\begin{gathered}
P=\frac{F}{n} \times 100 \% \\
P=\frac{3}{54} \times 100 \%=6 \%
\end{gathered}
$$

4) Presentase responden yang memilih aplikasi WhasApp Group

$$
\begin{gathered}
P=\frac{F}{n} \times 100 \% \\
P=\frac{8}{54} \times 100 \%=15 \%
\end{gathered}
$$

5) Presentase responden yang memilih selain aplikasi Zoom, Google Meet, Google classroom, dan WhatsApp Group

$$
P=\frac{F}{n} \times 100 \%
$$




$$
P=\frac{4}{54} \times 100 \%=7 \%
$$

Hasil presentase ditampilkan dalam diagram lingkaran berikut ini.

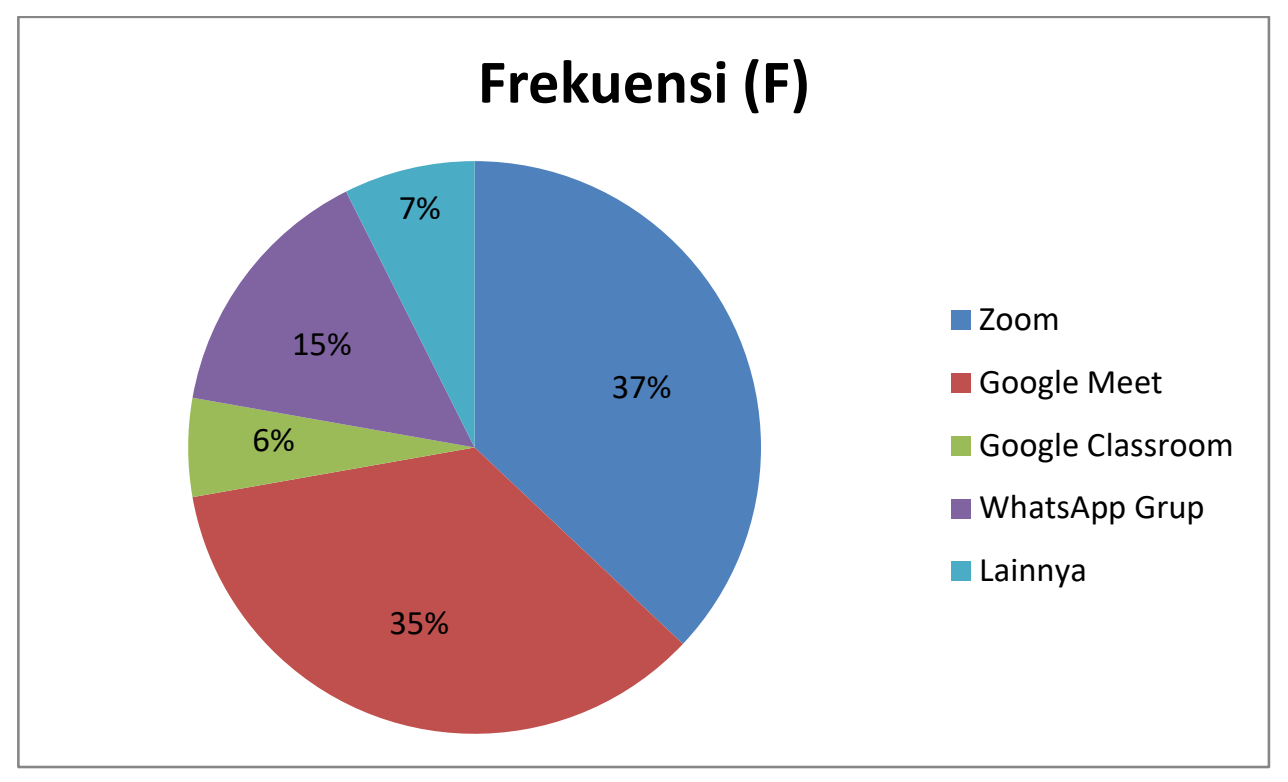

Berdasarkan data perhitungan di atas menunjukkan bahwa kebanyakan responden memilih aplikasi Zoom sebagai aplikasi andalan mereka dalam pembelajaran online. Lalu diikuti dengan Aplikasi Google Meet yang memiliki besar presentase yang cukup besar juga seperti pada Zoom. Kemudian disusul dengan WhatsApp group, Google Classroom, dan aplikasi atau media lainnya.

2. Apa alasan responden memilih aplikasi tersebut?

Dari hasil penelitian, pertanyaan tersebut mendapat beberapa respon yang cukup beragam. Respon-respon tersebut dirangkum seperti berikut ini :

1) Respon terhadap Zoom

- Dengan Zoom dapat bertatap muka secara virtual dan saling berkomunikasi dengan pengajar.

- Zoom terdapat fitur-fitur yang bervariasi dan lebih lengkap dibanding dengan aplikasi-aplikasi lainnya.

- Dengan Zoom lebih lancar.

- Dengan Zoom, jaringan lebih stabil dan kuota tidak boros.

2) Respon terhadap Google Meet

- Dengan Google Meet dapat bertatap muka secara virtual dan saling berkomunikasi dengan pengajar.

- Dengan Google Meet jarang mengalami kendala jaringan dan lebih hemat kuota daripada Zoom. 
- Google Meet tidak mengurans banyak ruang penyimpanan.

- Google Meet tidak dibatasi waktu dalam penggunaannya.

3) Google Classroom

- Dapat mendapatkan materi yang berikan oleh pengajar, mengirim tugas, dan kuis.

- Dapat dilampirkan link google meet untuk langsung terhubung video conference dan berdiskusi bersama disana.

4) WhatsApp Group

- Tidak memakan banyak data internet dan lebih bersahabat dengan jaringan internet.

- Materi yang disampaikan dapat dibaca atau didengar ulang.

- WhatsApp merupakan aplikasi yang paling sering digunakan oleh banyak orang sehingga lebih terbiasa.

5) Respon terhadap aplikasi lainnya

- Responden mengungkapkan bahwa semua aplikasi pembelajaran adalah efektif tergantung bagaiamana kita menyikapinya.

- Responden mengungkapkan bahwa aplikasi-aplikasi pembelajaran adalah saling melengkapi antara kelebihan dan kekurangannya.

- Responden mengungkapkan bahwa aplikasi pembelajaran yang digunakan telah ditentukan oleh lembaga pendidikan yang ditempatinya.

- Responden memilih dua aplikasi yaitu Zoom dan Google Meet sebagai aplikasi yang paling efektif dalam pembelajaran online.

Dari hasil respon dari para responden menggambarkan bahwa aplikasi Zoom dan Google Meet memiliki kelebihan yang hampir sama serta aplikasi-aplikasi lainnya yang presentasenya cukup rendah dinyatakan dengan respon yang cukup beragam.

Aplikasi Zoom sendiri merupakan aplikasi untuk berkomunikasi utamanya dalam bentuk video call yang mampu menampung orang dengan kapasitas yang cukup besar . “ Zoom cloud meetings merupakan sebuah aplikasi yang dapat menunjang suatu kebutuhan komunikasi dengan banyak orang tanpa harus kontak langsung. Aplikasi ini untuk videoconference. Aplikasi dapat diinstal dengan perangkat seperti, PC dengan webcame, laptop dengan webcame, dan juga smartphone Android " (Pratiwi, dkk, 2019:1749 ). Selain kapasitas yang besar, Zoom memiliki fitur-fitur beragam yang sangat cocok

digunakan dalam diskusi atau pembelajaran online, seperti background video yang dapat diubah, papan tulis, tempat untuk mengirim pesan, dll. Sedangkan Google Meet merupakan aplikasi yang hampir sama dengan Zoom, namun fitur yang dimiliki sedikit berbeda. Pada Google Meet kapasitas yang bisa dimuat dibatasi dan secara umum lebih sederhana dibanding dengan aplikasi Zoom. Untuk Google Classroom agak sedikit berbeda. Dalam Google Classroom, sistem yang digunakan adalah ketik atau tulis. Di sini kita dapat melakukan 
dikusi secara tulisan dengan didukung fitur-fitur seperti, unggah foto, dokumen, link, serta fitur sebagai pendukung kuis.

Lalu pada aplikasi WhatsApp, menurut Larasati, dkk (Dalam Rahartri : 2013), WhatsApp merupakan aplikasi untuk saling berkirim pesan, secara instan, dan memungkinkan kita untuk saling bertukar gambar, video, foto, pesan suara, dan dapat digunakan untuk berbagi informasi dan diskusi. Dalam WhatsApp terdapa fitur WhatsApp group yang bisa digunakan sebagai media diskusi online sehingga tak jarang pembelajaran online dilakukan pada WhatsApp Group. Sedangkan aplikasi lainnya selain Zoom, Google Meet, Google Classroom, dan WhatsApp, responden memilih aplikasi bernama Ms.Team yang merupakan aplikasi pembelajaran yang menurut pernyataan responde adalah aplikasi belajar telah ditetapkan penggunaannya oleh lembaga pendidikannya sendiri sehingga aplikasi ini tidak sembarang dapat diakses oleh banyak orang atau umum.

\section{KESIMPULAN}

1. Berdasarkan data hasil penilitian, aplikasi pilihan responden yang paling banyak dipilih adalah aplikasi Zoom dengan presentase 37\%, disusul dengan aplikasi Google Meet sebsar 35\%, Google Classroom 6\%, WhatsApp Group 15\%, dan apllikasi lainnya sebesar $7 \%$.

2. Berdasarkan besarnya presentase, aplikasi yang paling diminati menurut efektivitasnya oleh responden untuk digunakan dalam pembelajaran online adalah Zoom dan Google Meet. Di mana presentase kedua aplikasi tersebut memiliki selisih yang kecil sehingga besarnya peminatnya dalam dinilai sama.

3. Masing-masing aplikasi memiliki kelebihan dan kekurangan yang menjadikan aplikasi tersebut memiliki frekuensi responden yang berbeda-beda. Namun, pada aplikasi yang memilki presentase pemilihan paling besar yakni Zoom dan Google Meet menigndikasikan bahwa aplikasi tersebut memiliki jumlah peminat yang lebih besar di antara aplikasi-aplikasi yang lain.

\section{DAFTAR PUSTAKA}

Rahartri. (2019) . "WhatsApp Media” Komunikasi Efektif Masa Kini (Studi Kasus pada Pelayanan Jasa Informasi Ilmiah di Kawasan Puspitek).Visi Pustaka Vol.21, No.2. Diakses tanggal 25 Desember 2020 dari https://ejournal.perpusnas.go.id/vp/article/view/552

Hendrawati, Heni. (2016). Analisis Potensi Tenaga Kerja Lokal di Kawasan Bandara Internasional Jawa Barat (BIJB) di Kecamatan Kertajati Kabupaten Majalengka. Diakses tanggal 25 Desember 2020 dari

http://repository.upi.edu/27179/5/S_GEO_0906938_Chapter3.pdf

Pratiwi, Dwi Anggi.dkk. (2019). Potensi Aplikasi Zoom Cloud Meetings Dalam

Pembelajaran Di Era Digita. Diakses tanggal 2 Januari 2020 dari

https://www.researchgate.net/publication/343859632_POTENSI_APLIKASI_ZOOM_CLOU D_MEETINGS_DALAM_PEMBELAJARAN_DI_ERA_DIGITAL 
